\title{
Wpływ sposobu modelowania przęsel mostów niskowodnych na wartość maksymalnych naprężeń w dźwigarach głównych
}

\author{
Artur Duchaczek \\ Wydział Zarzadzania, Wyższa Szkoła Oficerska Wojsk Ląowych \\ imienia generała Tadeusza Kościuszki,e-mail: aduchaczek@poczta.wp.pl
}

Streszczenie: Ze względu na czas niezbędny do zbudowania modelu obliczeniowego stalowa konstrukcja nośna mostów niskowodnych zazwyczaj modelowana jest jako ruszt przy wykorzystaniu prętowych elementów skończonych, tzw. modele „prętowe”. Zastosowanie prętowych elementów skończonych do modelowania dźwigarów głównych mostów niskowodnych uniemożliwia uwzględnienie rzeczywistego położenia pokładu drewnianego w stosunku do osi obojętnej tychże dźwigarów. Z tego względu w niniejszym artykule zaprezentowano możliwość wykorzystania do modelowania dźwigarów głównych powierzchniowych elementów skończonych, tworząc tzw. modele ,powłokowe”. W wyniku przeprowadzonych analiz numerycznych stwierdzono, że modelem preferowanym do obliczeń wojskowych przęseł mostów niskowodnych powinien być model ,powłokowy”, w którym w obliczeniach nie uwzględniano usztywnienia modelu przęsła pokładem drewnianym. Model ten umożliwia dość dokładną analizę rozkładu naprężeń w wybranych elementach konstrukcji rusztu stalowego, co jest istotne chociażby przy analizie rozwoju potencjalnych pęknięć zmęczeniowych. W przypadku obliczeń przęseł mostów niskowodnych nastawianych tylko na określenie ogólnej nośności wybranej konstrukcji przęsła wystraczającymi modelami okazały się modele wykorzystujące tylko prętowe elementy skończone.

Słowa kluczowe: metoda elementów skończonych, most niskowodny, konstrukcje stalowe, przęsło.

\section{Wprowadzenie}

Mosty niskowodne [1] charakteryzują się podobnymi rozwiązaniami konstrukcyjnymi jak cywilne obiekty mostowe nazywane mostami objazdowymi lub tymczasowymi (rys. 1). W literaturze obcojęzycznej mosty tego typu nazywane są „low-water bridge” [2], a jeżeli dotyczą mostów wojskowych to także ,military nonstandard fixed bridges” [3].

Nieodzownym narzędziem współczesnego inżyniera jest oprogramowanie komputerowe. Większość programów wykorzystywanych do oceny nośności elementów konstrukcyjnych oparta jest na metodzie elementów skończonych (MES) [4], [5]. Oprogramowanie to umożliwia analizę zarówno całych obiektów inżynierskich, jak i wybranych ich elementów konstrukcyjnych. Oprogramowaniem chętnie wykorzystywanym przez inżynierów budownictwa jest program Robot Structural Analysis Professional firmy Autodesk [6].

W pracach [7], [8], [9] zaprezentowano możliwość wykorzystania tego oprogramowania do oceny nośności konstrukcji mostów niskowodnych, poprzez analizę wpływu ilości i jakości belek poprzecznych (poprzecznic) oraz sposobu ich montażu na wartość maksymalnych naprężeń w dźwigarach głównych. W dotychczasowych obliczeniach [7], [8], [9] konstrukcję nośną tego typu mostu modelowano jako ruszt, przy wykorzystaniu 
prętowych elementów skończonych. Tak uproszczony sposób modelowania mostów niskowodnych był wystarczający w przypadku ogólnej oceny nośności przęsła analizowanego mostu, nie nadawał się natomiast do szczegółowej analizy naprężeń w wybranych elementach konstrukcyjnych. Wynikało to z faktu, że zastosowanie elementów prętowych uniemożliwia uwzględnienie rzeczywistego położenia pokładu drewnianego w stosunku do osi obojętnej stalowych dźwigarów głównych, co skutkowało równomiernym obciążeniem pasa dolnego i górnego modelowanych kształtowników stalowych.

Z tego też względu, w niniejszym artykule zaprezentowano możliwość wykorzystania oprogramowania Robot Structural Analysis Professional firmy Autodesk opartego na metodzie elementów skończonych do oceny wpływu sposobu modelowania przęseł mostów niskowodnych na wartość maksymalnych naprężeń w stalowych dźwigarach głównych.

\section{Konstrukcja przęsła i przyjęte obciążenie}

Uwzględniając fakt, że pojazdy będące na wyposażeniu polskich sił zbrojnych mają zbliżone gabaryty do pojazdów klasy MLC40 $\div$ MLC70 [10], zatem w niniejszej pracy podobnie jak w pracach [7], [8], [9], jako obciążenie obliczeniowe przyjęto obciążenie gąsienicowe klasy MLC70. Pojazdy tej klasy charakteryzują się masą całkowitą 63,50 tony, szerokością pojazdu (na wysokości gąsienic) 3,51 m, szerokością gąsienic $0,79 \mathrm{~m}$ i długością przylegania gąsienicy równą 4,57 $\mathrm{m}$ [10].

W niniejszej pracy do analizy przyjęto most jednokierunkowy, którego konstrukcja była już uwzględniona w analizach w pracach [7], [8] i [9]. Przęsło to składa się z sześciu dźwigarów głównych wykonanych z dwuteowników stalowych INP 400 o długości $14 \mathrm{~m}$ i szerokości jezdni równej 4,00 m. Belki poprzeczne wykonano z dwuteowników szerokostopowych HEB200 o wysokości profilu poprzecznego równej 200 mm (rys. 2).

Pokład drewniany wykonano w dwóch wariantach. Wariant I uwzględniał pokład drewniany wykonany $\mathrm{z}$ dwóch warstw desek (pokład poprzeczny i podłużny), każda o grubości $5 \mathrm{~cm}$ ułożonych prostopadle do siebie i połączonych za pomocą gwoździ (rys. 2b). W tym przypadku pokład drewniany można traktować jako w miarę jednorodną płytę drewnianą. W wariancie II pokład składał się tylko z pokładu poprzecznego wykonanego $\mathrm{w}$ formie bali drewnianych (rys. 2a).

W wojskowych mostach niskowodnych pokład drewniany zazwyczaj mocowany jest przy użyciu drewnianych krawężników i śrub krawężnikowych do skrajnych dźwigarów głównych. Pokład ten nie współpracuje zatem w sposób idealny ze stalowym rusztem, ponieważ brak jest jego bezpośredniego mocowania z wszystkimi dźwigarami głównymi. Pokład ten wraz z belkami poprzecznymi uczestniczy natomiast w rozdziale i przekazaniu obciążenia na wszystkie dźwigary główne [9].

a)

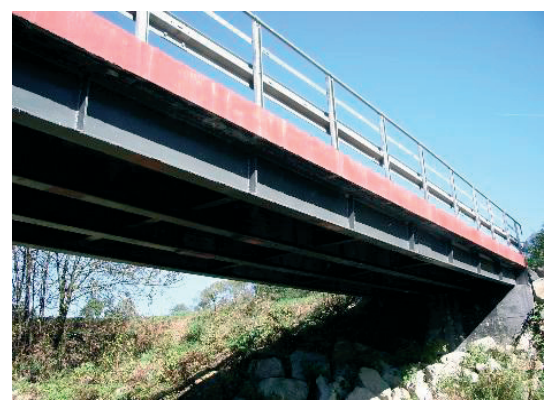

b)

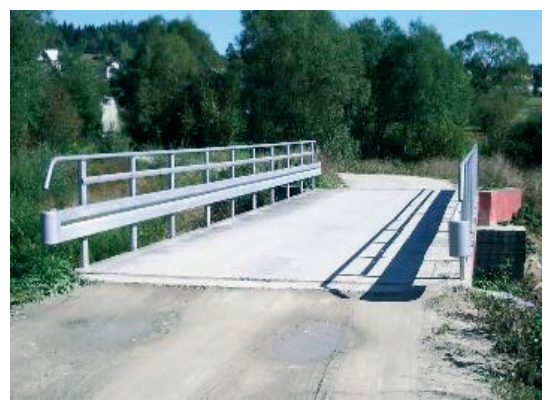

Rys. 1. Widok mostu niskowodnego: a) z boku, b) od dojazdu (fot. A. Duchaczek) 
a)

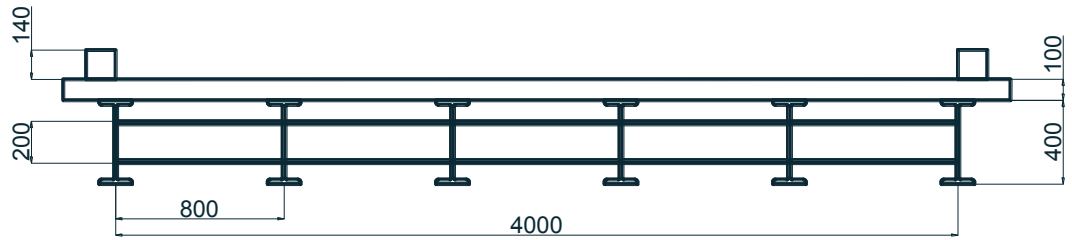

b)

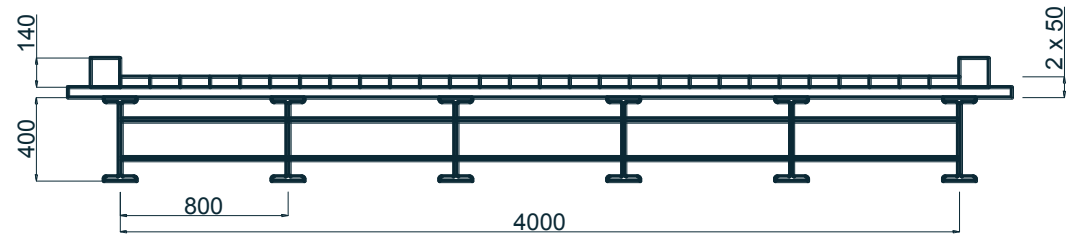

Rys. 2. Przekrój poprzeczny analizowanego przęsła mostu z pokładem: a) poprzecznym, b) poprzecznym i ochronnym

\section{Modelowanie przęsła i obliczenia}

W prowadzonych analizach przęsło mostu zostało zamodelowane, zarówno jako tzw. konstrukcja „powłokowa” oraz ,prętowo-powłokowa” [6]. Konstrukcja „powłokowa” miała zaprezentować możliwość wykorzystania oprogramowania firmy Autodesk do oceny nośności mostów niskowodnych, przy wykorzystaniu do ich modelowania tylko powierzchniowych elementów skończonych. Konstrukcja ,prętowo-powłokowa”, omawiana już w pracach [8], [9], wykorzystywana była jedynie do porównania wyników obu rozpatrywanych konstrukcji.

W przypadku konstrukcji „prętowo-powłokowej” stalowa konstrukcja nośna została zamodelowana jako ruszt przy wykorzystaniu 2-węzłowych prętowych elementów skończonych. Zarówno dźwigary główne, jak i belki poprzeczne zamodelowano jako kształtowniki stalowe. W przypadku konstrukcji „powłokowej” stalowa konstrukcja nośna została zamodelowana przy wykorzystaniu tzw. „paneli” o grubości odpowiadającej danym elementom kształtowników, tj. pasom i środnikowi. W procesie dyskretyzacji kształtowników stalowych wykorzystano metodę siatkowania Coons z zastosowaniem czworokątnych 4-węzłowych elementów powierzchniowych o rozmiarze $10 \mathrm{~cm}$ [6]. Do obliczeń numerycznych, podobnie jak we wcześniejszych pracach przyjęto, że wszystkie kształtowniki zostały wykonane ze stali gatunku S355, o następujących parametrach: moduł Younga $E=210 \mathrm{GPa}$, moduł Kirchoffa $G=81 \mathrm{GPa}$, ciężar właściwy $\gamma=77,01 \mathrm{kN} / \mathrm{m}^{3}$ [8], [9].

Pokład drewniany został zamodelowany jako jeden ,panel” o grubości $10 \mathrm{~cm}$ [6]. W procesie dyskretyzacji pokładu wykorzystano również metodę siatkowania Coons z zastosowaniem czworokątnych 4-węzłowych elementów powierzchniowych o rozmiarze $10 \mathrm{~cm}$. Płytę pomostu zamodelowano z drewna klasy C14 o module Younga $E=7000 \mathrm{MPa}$, module Kirchoffa $G=3500 \mathrm{MPa}$ i ciężarze właściwym $\gamma=2,84 \mathrm{kN} / \mathrm{m}^{3}$ [8], [9]. W obliczeniach numerycznych model materiału płyty drewnianej przyjęto dla wariantu I jako materiał jednorodny, natomiast dla wariantu II jako materiał ortotropowy, korzystając z opcji tzw. „ortotropii materiałowej”. Ta opcja programu umożliwia zadeklarowanie dla analizowanego „panelu” dwóch różnych wartości modułu Younga E, mającego bezpośredni wpływ na wartość sztywności konstrukcji. Dla wariantu II określając parametry pokładu drewnianego przyjęto $\mathrm{w}$ kierunku podłużnym przęsła moduł Younga $E=0,0001 \mathrm{MPa}$, co powodowało niemalże zerową sztywność pokładu poprzecznego wzdłuż osi przęsła. Taki model pokładu miał odzwierciedlać w obliczeniach pokład poprzeczny wykonanych z bali drewnianych (rys. 2a). 
W obliczeniach numerycznych wykorzystano pojazd gąsienicowy klasy MLC70 modelując go jako obciążenie symetryczne (G1) i niesymetryczne (G2). Podobnie jak we wcześniejszych pracach [7], [8] i [9], w obliczeniach nie uwzględniono obciążeń środowiskowych, takich jak wiatr i śnieg. W niniejszej pracy w obliczeniach numerycznych wykorzystano również opcję tzw. „obciążenia ruchomego”, w której określano parametry pojazdu oraz drogę jego przemieszczania się po analizowanej konstrukcji. Uwzględniając fakt, że pokład zamodelowano jako tzw. panel, z wykorzystaniem powierzchniowych elementów skończonych, do konstrukcji można było przykładać obciążenie pojazdem gąsienicowym zdefiniowane jako obciążenie powierzchniowe (tzw. konturowe) [6]. Obciążenie to jest generowane na każdym panelu, który znajduje się w obrębie rzutu konturu obciążenia. Dla celów porównawczych obciążenie gąsienicowe MLC70 w jednym z przypadków obliczeniowych przykładane było tylko do konstrukcji prętowej, tzn. bez uwzględnienia pokładu drewnianego (M3). Do konstrukcji prętowych typu ruszt można przykładać obciążenia pojazdem gąsienicowym zdefiniowanym jako obciążenie ciągłe (liniowe). W przypadku obciążenia ciągłego musiało ono najpierw zostać zastąpione 10 siłami skupionymi na długości przyjętego obciążenia odpowiadającego długości przylegania gąsienicy. Jeżeli siły skupione nie znajdowały się bezpośrednio nad prętem, wówczas stosowany był algorytm rozkładający ją na najbliższe pręty [6]. W większości przypadków obliczeniowych analizowanych (zarówno model ,powłokowy”, jak i „prętowo-powłokowy”) obciążenie użytkowe G1 i G2 przekazywane było na pokład drewniany, a stąd dopiero na kształtowniki stalowe będące elementami nośnymi konstrukcji mostu.

W obliczeniach numerycznych uwzględniany był również ciężar własny konstrukcji określony jako obciążenie G0. Dla modeli obliczeniowych M1, M2, M4 i M5 ciężar własny całej konstrukcji (obciążenie G0) uwzględniany był automatycznie przez program Robot (tabela 1). W przypadku modeli M3 i M6, dla których w obliczeniach numerycznych nie uwzględniano pokładu drewnianego wprowadzono dodatkowe obciążenie stałe (tabela 1).

W modelu M3 było to obciążenie liniowe $q_{1}$ przyłożone do prętowych elementów skończonych modelujących dźwigary główne, natomiast w modelu M6 było to obciążenie powierzchniowe $q_{2}$ przyłożone do paneli (powierzchniowych elementów skończonych) modelujących pasy górne dźwigarów głównych (tabela 1).

W tabeli 1 przedstawiono sześć przyjętych w pracy modeli obliczeniowych przęsła, dla których wykonano symulacje numeryczne. Na rys. 3 i 4 zaprezentowano natomiast wybrane modele obliczeniowe analizowanego przęsła. Dla modeli obliczeniowych, w których drewniany pokład występuje zarówno w formie płyty, jak i w formie pojedynczego pokładu poprzecznego jego graficzne zobrazowanie nie różni się.

Tabela 1. Opis modeli obliczeniowych wykorzystywanych w obliczeniach numerycznych

\begin{tabular}{lcccccc}
\hline \multirow{2}{*}{ Wyszzzególnienie } & \multicolumn{5}{c}{ Model obliczeniowy } \\
\cline { 2 - 6 } & M1 & M2 & M3 & M4 & M5 & M6 \\
\hline $\begin{array}{l}\text { Elementy skończone wykorzystane } \\
\text { do modelowania stalowego rusztu }\end{array}$ & Plementy prętowe & Elementy powierzchniowe \\
\hline Pokład drewniany & $\begin{array}{c}\text { Powierzchniowe } \\
\text { (konturowe) }\end{array}$ & Ciągłe liniowe & $\begin{array}{c}\text { Powierzchniowe } \\
\text { (konturowe) }\end{array}$ \\
\hline Rodzaj obciążenia & $\begin{array}{c}\text { Pokład } \\
\text { drewniany }\end{array}$ & $\begin{array}{c}\text { Bezpośrednio na } \\
\text { elementy rusztu }\end{array}$ & $\begin{array}{c}\text { Pokład } \\
\text { drewniany }\end{array}$ & $\begin{array}{c}\text { Tzw. okła- } \\
\text { dzina }\end{array}$ \\
\hline $\begin{array}{l}\text { Element przekazujący obciążenie na } \\
\text { stalowy ruszt }\end{array}$ & 1a & 1b & 1c & 1d \\
\hline Graficzna prezentacja na rysunku & & & Brak & Płyta \\
\hline
\end{tabular}


a)

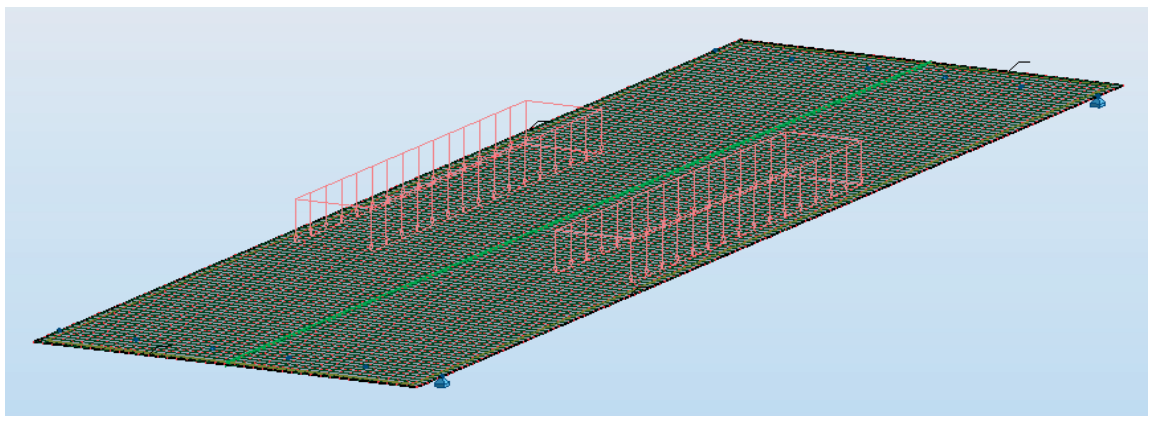

b)

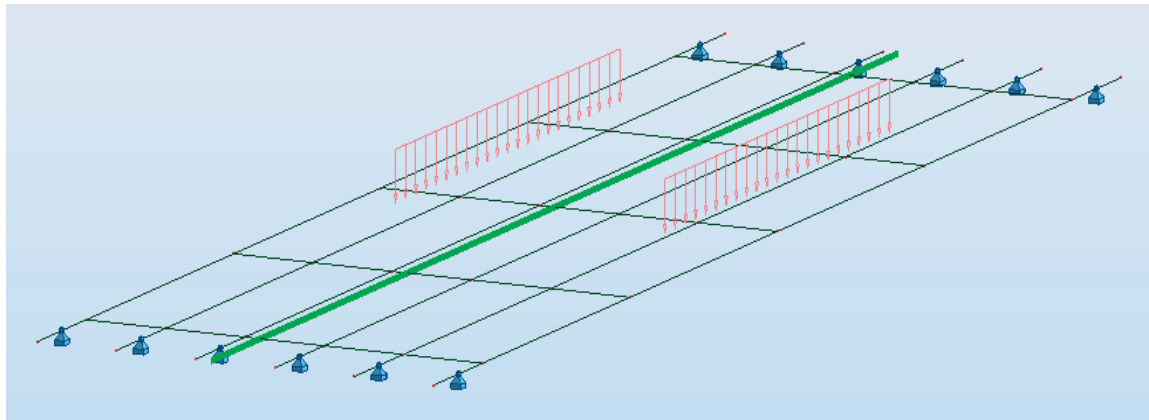

Rys. 3. Graficzne zobrazowanie modeli obliczeniowych przęsła z rusztem stalowym jako układem „prętowo-powłokowym” i „prętowym”, w których zastosowano obciążenie ruchome: a) model „prętowopowłokowy” M1(M2) - obciążenie symetryczne G1, b) model „prętowy” M3 - obciążenie niesymetryczne G2

a)

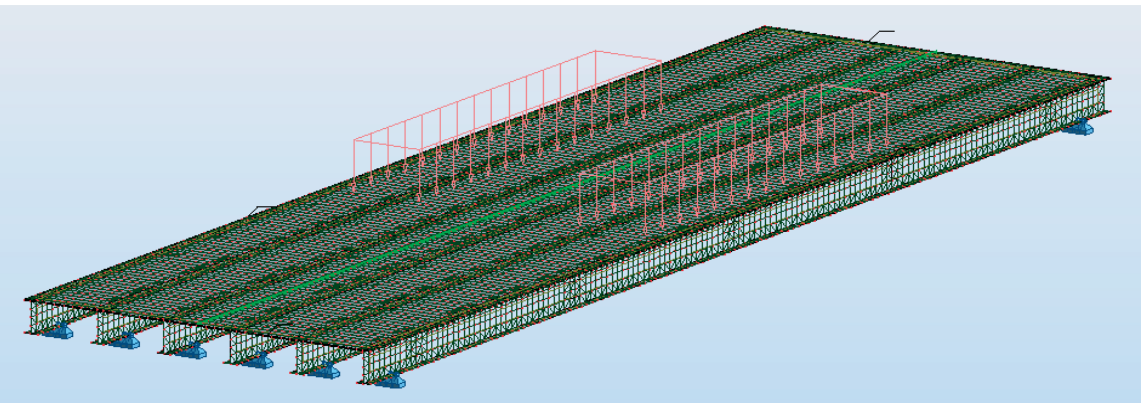

b)

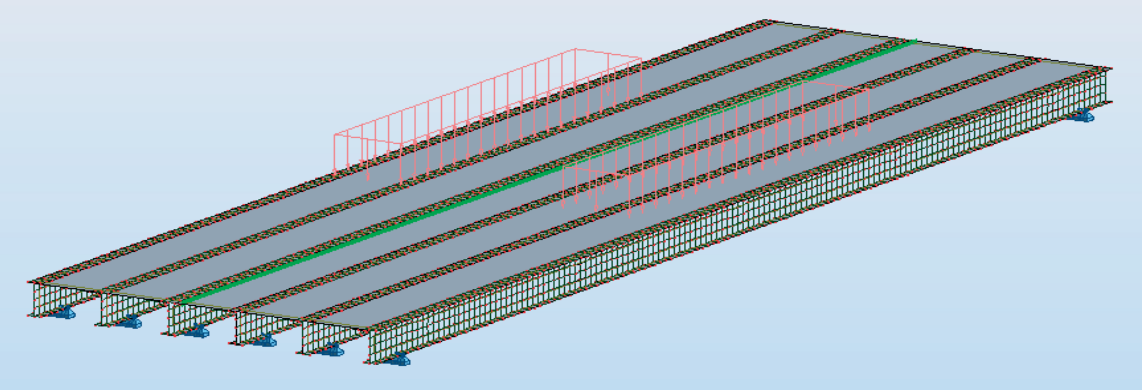

Rys. 4. Graficzne zobrazowanie wybranych modeli obliczeniowych przęsła z rusztem stalowym jako układem ,powłokowym”, w których zastosowano obciążenie ruchome: a) model M4(M5) - obciążenie symetryczne G1, b) model M6 (z tzw. „okładziną” [6]) - obciążenie niesymetryczne G2 


\section{Wyniki analiz numerycznych}

Na rys. 5 zaprezentowano graficzną prezentację przykładowych wyników przeprowadzonych analiz numerycznych. W tablicy 2 i na rys. 6 zaprezentowano wyniki tych analiz dla sześciu modeli obliczeniowych przęsła (M1-M6) oraz trzech modeli obciążenia (G0G2). W tym przypadku ze względu na zmianę znaku naprężeń normalnych w pasie dolnym (na ujemne) w zaprezentowanych zestawieniach nie uwzględniono wyników obliczeń dotyczących strefy przypodporowej, mimo że dla modeli obliczeniowych M4-M6 dla pasa dolnego największe ujemne naprężenia normalne występowały właśnie w tej strefie.

a)

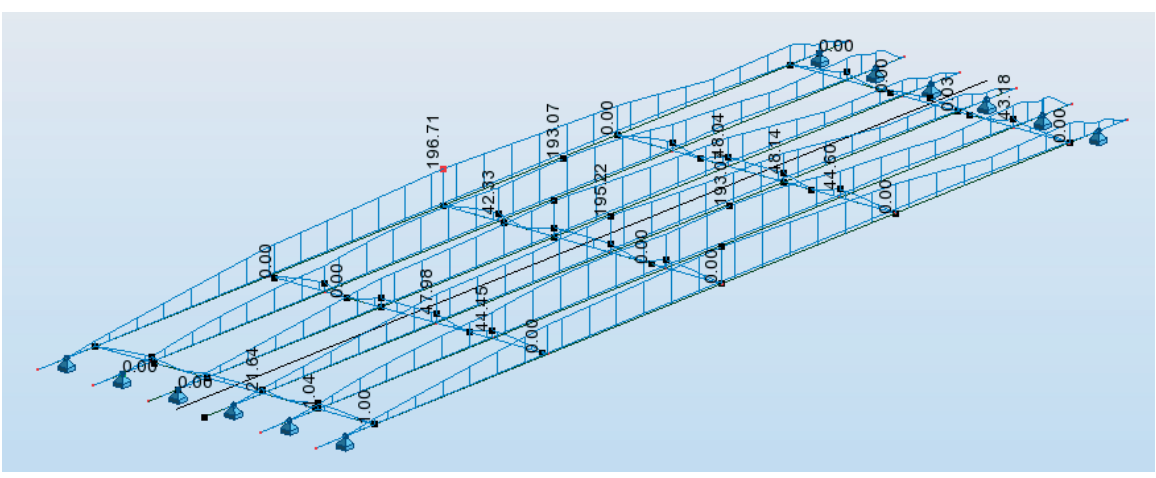

b)

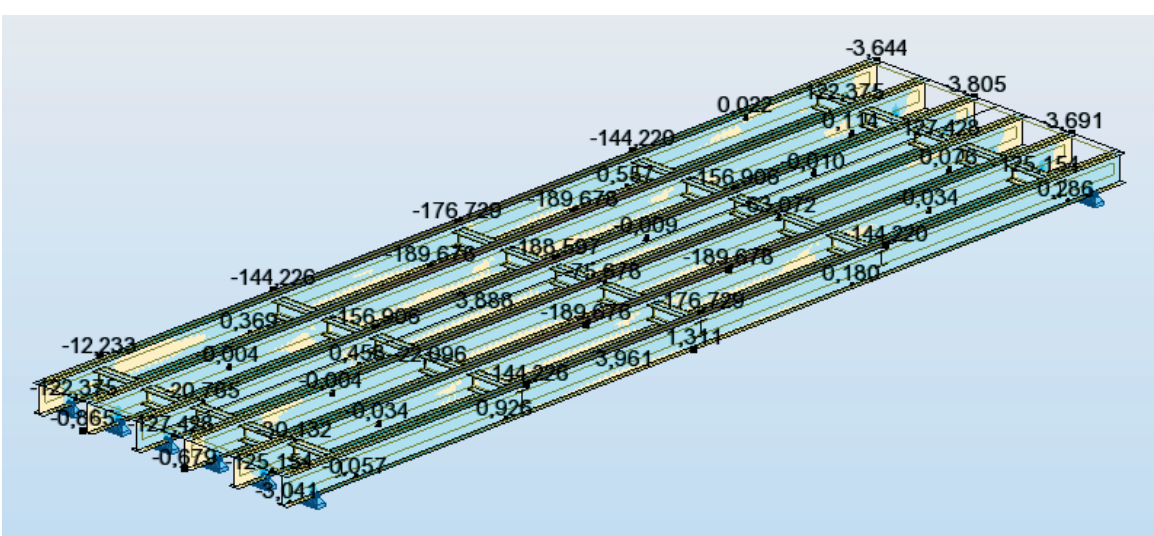

Rys. 5. Graficzna prezentacja wyników analiz numerycznych (naprężenia normalne) dla modelu: a) prętowego M3, b) powłokowego M6, przęsła w przypadku schemat obciążenia G1

Tabela 2. Wartość naprężeń normalnych w dźwigarach głównych w kierunki podłużnym przęsła [MPa] (bez uwzględniania strefy przypodporowej) dla modelu obciążenia: a) G0, b) G1 i c) G2

\begin{tabular}{|c|c|c|c|c|c|c|c|}
\hline \multirow{2}{*}{$\begin{array}{l}\text { Wyszcze- } \\
\text { gólnienie }\end{array}$} & \multirow{2}{*}{$\begin{array}{l}\text { Schemat } \\
\text { obciążenia }\end{array}$} & \multicolumn{6}{|c|}{$\begin{array}{l}\text { Wartość naprężeń normalnych w dźwigarach głównych w kierunki podłużnym } \\
\text { przęsła [MPa] dla modelu obliczeniowego przęsła }\end{array}$} \\
\hline & & M1 & M2 & M3 & M4 & M5 & M6 \\
\hline \multirow{3}{*}{$\begin{array}{l}\text { Pas } \\
\text { górny }\end{array}$} & G0 & $-17,66$ & $-17,81$ & $-17,80$ & $-10,64$ & $-14,34$ & $-14,95$ \\
\hline & G1 & $-196,51$ & $-197,48$ & $-196,71$ & $-137,85$ & $-137,66$ & $-189,68$ \\
\hline & G2 & $-237,91$ & $-243,88$ & $-243,53$ & $-164,04$ & $-177,57$ & $-226,03$ \\
\hline \multirow{3}{*}{$\begin{array}{l}\text { Pas } \\
\text { dolny }\end{array}$} & G0 & 17,66 & 17,81 & 17,80 & 5,61 & 5,94 & 5,87 \\
\hline & G1 & 196,51 & 197,48 & 196,71 & 69,12 & 70,75 & 99,68 \\
\hline & G2 & 237,91 & 243,88 & 243,53 & 89,05 & 93,98 & 130,89 \\
\hline
\end{tabular}


Analiza wartości naprężeń normalnych w dźwigarach głównych w kierunki podłużnym przęsła dla przyjętych modeli obliczeniowych przęsła wykazuje, że ,prętowy” i ,prętowo-powłokowy” model rusztu, który uniemożliwia uwzględnienie rzeczywistego położenia pokładu względem dźwigarów głównych wykazuje większe wartości naprężeń normalnych. W modelu tym wartość naprężeń w górnych i dolnych pasach dwuteownika są identycznych wielkości (różnią się tylko znakiem). Dla tego typu modeli przęsła (M1-M3) nie miał większego znaczenia zarówno fakt uwzględnienia pokładu, jak i sposób jego modelowania.

W przypadku przęsła zamodelowanego jako konstrukcja „powłokowa” w strefie międzypodporowej obserwujemy znacznie mniejsze wartości naprężeń, zarówno w pasie górnym, jaki i dolnym. Analizując wartość naprężeń normalnych dla modeli obliczeniowych M4-M6 należy stwierdzić, że uwzględnienie w obliczeniach pokładu drewnianego jako płyty (model M4) usztywnia konstrukcję, a przez to wartości naprężeń maksymalnych w dźwigarach są najmniejsze. Dla modelu M5 z pokładem porzecznym, w którym zastosowano tzw. „ortotropię materiałową” [6] wartości naprężeń są nieznacznie większe niż w modelu M4. Największe wartości naprężeń odnotowano dla modelu przęsła M6, w którym pokład drewniany potraktowano tylko jako dodatkowe obciążenie stałe $q_{2}$, nie uwzględniając w żaden sposób jego sztywności. Na uwagę zasługuje również fakt, że dla tych modeli obliczeniowych przęsła (M4-M6) w strefie międzypodporowej wartości naprężeń w pasie dolnym są zdecydowanie mniejsze niż naprężenia w pasie górnym.

W tablicy 3 i na rys. 7 zaprezentowano wartości naprężeń zredukowanych w dźwigarach głównych uzyskane w wyniku analiz numerycznych dla trzech ,powłokowych” modeli obliczeniowych przęsła (M4-M6) oraz trzech modeli obciążenia (G0-G2).

Analiza danych w tabeli 2 i 3 wykazała, że wartości naprężeń normalnych wzdłuż osi podłużnej przęsła, jak i naprężeń zredukowanych w pasie dolnym w strefie międzypodporowej są na podobnym poziomie.

Wykresy zaprezentowane na rys. 7 wskazują, że wartości naprężeń zredukowanych w pasie górnym w strefie międzypodporowej również znacznie przekraczają wartość naprężeń zredukowanych w pasie dolnym w strefie przypodporowej. Różnica między tymi wynikami jest jednak mniejsza niż między wartością naprężeń zredukowanych w obu pasach dla strefy międzypodporowej (tabela 3 ).

Tabela 3. Wartość naprężeń zredukowanych w dźwigarach głównych i belkach poprzecznych [MPa]

\begin{tabular}{|c|c|c|c|c|c|}
\hline \multirow{2}{*}{\multicolumn{2}{|c|}{ Wyszczególnienie }} & \multirow{3}{*}{$\begin{array}{c}\text { Schemat obcią- } \\
\text { żenia } \\
\text { G0 }\end{array}$} & \multicolumn{3}{|c|}{ Wartość naprężeń zredukowanych [MPa] } \\
\hline & & & M4 & M5 & M6 \\
\hline \multirow{3}{*}{$\begin{array}{l}\text { Pas } \\
\text { górny }\end{array}$} & \multirow{3}{*}{$\begin{array}{c}\text { Strefa między- } \\
\text { podporowa }\end{array}$} & & 10,61 & 14,31 & 14,85 \\
\hline & & $\mathrm{G} 1$ & 144,92 & 159,25 & 186,29 \\
\hline & & $\mathrm{G} 2$ & 177,30 & 192,31 & 244,93 \\
\hline \multirow{6}{*}{$\begin{array}{l}\text { Pas } \\
\text { dolny }\end{array}$} & \multirow{3}{*}{$\begin{array}{l}\text { Strefa między- } \\
\text { podporowa }\end{array}$} & G0 & 5,42 & 5,88 & 5,90 \\
\hline & & G1 & 67,21 & 73,67 & 100,60 \\
\hline & & G2 & 79,57 & 93,94 & 125,26 \\
\hline & \multirow{3}{*}{$\begin{array}{c}\text { Strefa przypodpo- } \\
\text { rowa }\end{array}$} & G0 & 10,26 & 11,87 & 12,92 \\
\hline & & G1 & 91,81 & 93,98 & 134,05 \\
\hline & & G2 & 118,19 & 121,19 & 175,03 \\
\hline
\end{tabular}


a)

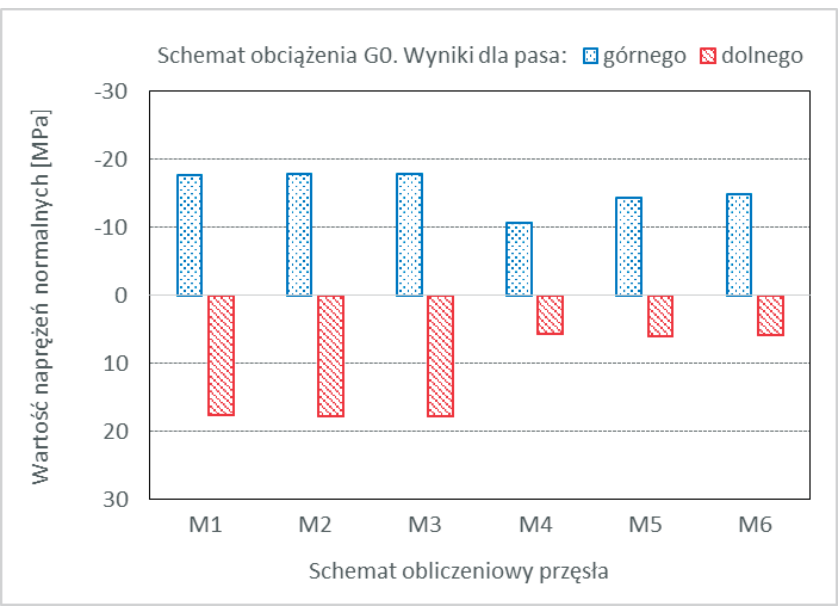

b)

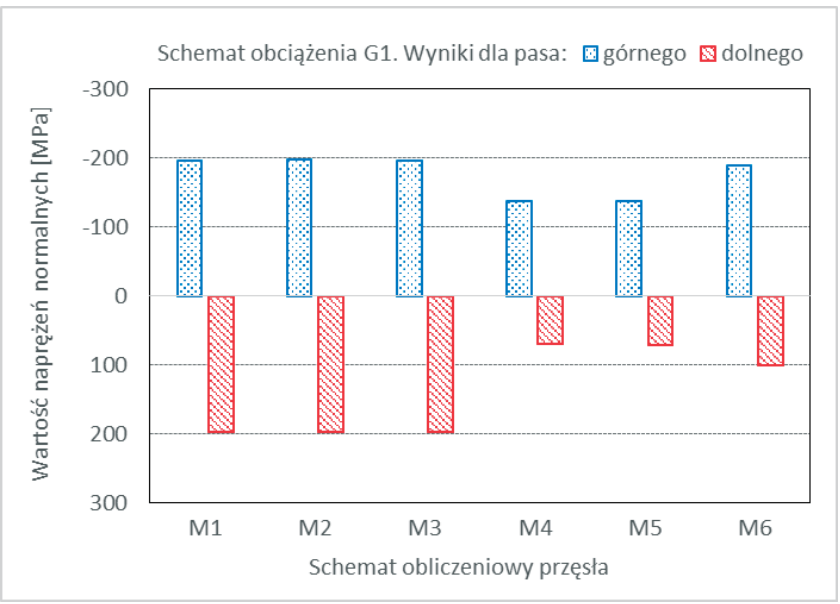

c)

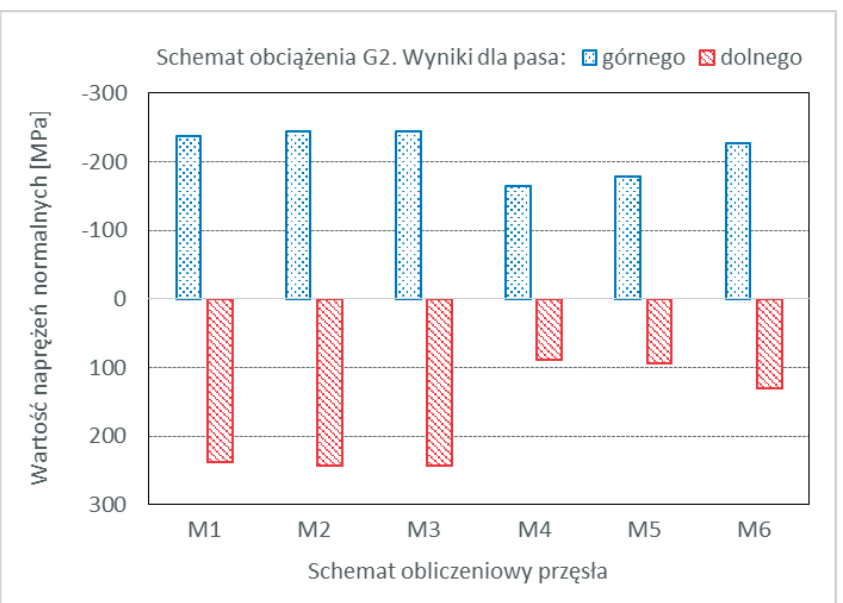

Rys. 6. Wartość naprężeń normalnych w dźwigarach głównych w kierunki podłużnym przęsła [MPa] (bez uwzględniania strefy przypodporowej) w przypadku modelu obciążenia: a) G0, b) G1 i c) G2 
a)

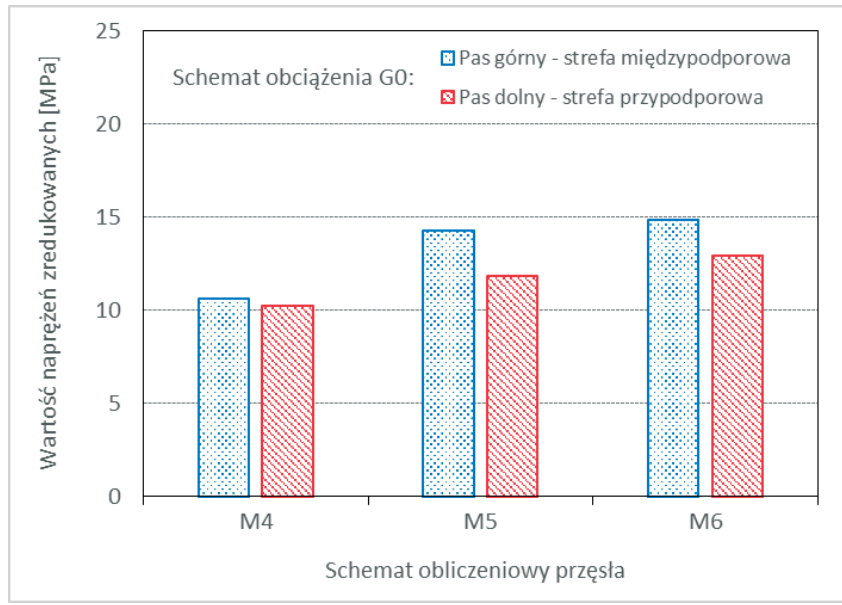

b)

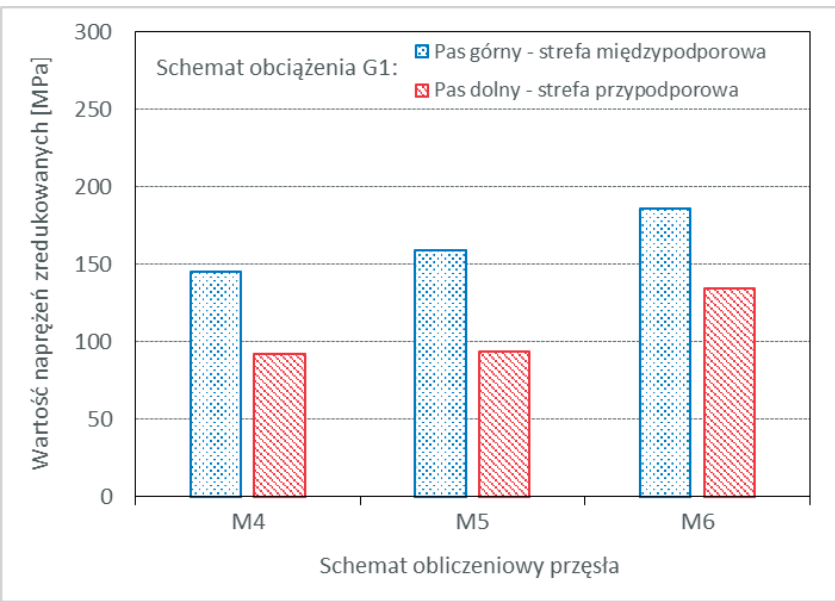

c)

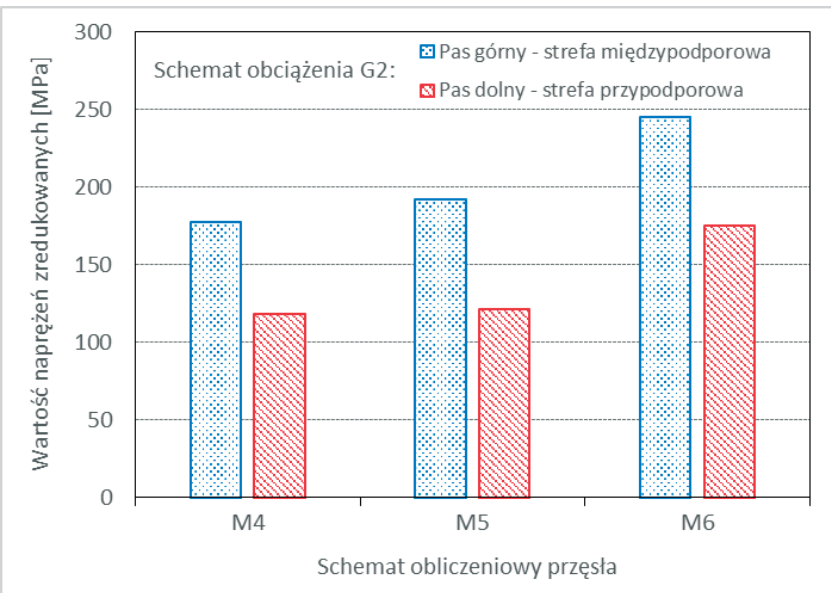

Rys. 7. Wartość naprężeń zredukowanych w dźwigarach głównych [MPa] w przypadku modelu obciążenia: a) G0, b) G1 i c) G2 


\section{Podsumowanie}

Z przeprowadzonej analizy wynika, że w modelu ,powłokowym” przęsła występują mniejsze wartości dodatnich (rozciągających) naprężeń normalnych w pasie dolnym dźwigarów stalowych, co ze względu chociażby na inicjację pęknięć zmęczeniowych jest zjawiskiem korzystnym. Analiza przeprowadzonych obliczeń numerycznych wykazuje zatem, że modelowanie przęseł mostów niskowodnych z zastosowaniem powierzchniowych elementów skończonych (tzw. konstrukcje „powłokowe”) umożliwia bardziej ekonomiczne ich projektowanie.

Należy jednak zaznaczyć, że w rzeczywistych warunkach poligonowych wykonywanie na tyle stabilnego połączenia pokładu drewnianego z dźwigarami stalowymi aby w obliczeniach można było potraktować całą konstrukcję jako konstrukcję monolityczną jest praktycznie niewykonalne. Można zatem uznać, że modelem ,,powłokowym” dopuszczalnym do obliczeń wojskowych przęseł mostów niskowodnych powinien być model M6, w którym w obliczeniach nie uwzględniano usztywnienia modelu płytą drewnianą.

Model „powłokowy” M4 może być stosowany natomiast do oceny nośności przęseł mostów, w których płyta pomostu wykonana jest z betonu (żelbetu) (rys. 1). Tego typu konstrukcje są często wykonywane przez pododdziały wojsk inżynieryjnych na rzecz ludności cywilnej w ramach odbudowy zniszczeń popowodziowych [11], [12].

Można jednak stwierdzić, że w przypadku obliczeń przęseł mostów niskowodnych nastawianych przede wszystkim na określenie ogólnej nośności wybranej konstrukcji przęsła wystarczająco bezpiecznymi modelami (tj. dającymi bardzo wysokie wartości naprężeń) okazują się bardzo proste i mało czasochłonne w modelowaniu konstrukcje „prętowo-powłokowe” (M1-M2). Zaletą tego typu konstrukcji, jest również fakt, że w programie Autodesk Robot istnieje możliwość uwzględnienia stopniowych zwolnień w połączeniach projektowanego rusztu [9], czego nie umożliwia zastosowanie konstrukcji „powłokowych”.

\section{Literatura}

1. Mosty wojskowe. Podręcznik, Ministerstwo Obrony Narodowej, Szefostwo Wojsk Inżynieryjnych, Sygnatura Inż. 563/92, Warszawa, 1994

2. McDonald T., Anderson-Wilk M. Low Water Stream Crossings in Iowa. A Selection and Design Guide. Iowa State University, 2003

3. Ray J. C.; Seda-Sanabria Y. Technical Commentary on FM3-34.343," Military Nonstandard Fixed Bridging". Engineer Research and Development Center Vicksburg ms Geotechnical and Structures LAB, 2002.

4. Rusiński E., Czmochowski J., Smolnicki T. Zaawansowana metoda elementów skończonych w konstrukcjach nośnych. Oficyna Wydawnicza Politechniki Wrocławskiej, 2000.

5. Zienkiewicz O.C. Metoda elementów skończonych. 1972.

6. Autodesk Robot Structural Analysis 2010. Podręcznik Użytkownika. Autodesk Inc., Marzec 2009.

7. Duchaczek A., Wplyw liczby poprzecznic na rozkład naprężeń w przęsłach mostów niskowodnych, Budownictwo i Architektura, 14(2) (2015) 27-35

8. Duchaczek A. The impact of cross beam on stresses of girders in low water bridges. XIII Międzynarodowa Konferencja Naukowa "Computer Aided Engineering", Polanica Zdrój 2225.06.2016 r.

9. Duchaczek A. Analiza numeryczna wplywu wymiarów belek poprzecznych i sposobu ich mocowania na maksymalne wartości naprężeń w dźwigarach głównych mostów niskowodnych, zdane do redakcji czasopisma Budownictwo i Inżynieria Środowiska - Civil and Environmental Engineering. 
10. STANAG 2021. Military Load Classification of Bridges. Edition no. 6. 7 September 2006.

11. Uroczyste otwarcie mostu w Skawie, http://www.2pinz.wp.mil.pl/pl/59_53.html, online: 16.11.2014 r.

12. Uroczyste otwarcie mostu w Kasinie Wielkiej, http://www.2pinz.wp.mil.pl/pl/59_67.html, online: 16.11.2014 r.

\title{
Influence of modeling of low-water bridge spans on the maximum value of stress in the main girders
}

\author{
Artur Duchaczek \\ Faculty of Management, General Tadeusz Kosciuszko Military Academy of Land Forces, \\ e-mail:aduchaczek@poczta.wp.pl
}

\begin{abstract}
Due to the time needed to create a computational model, the steel construction of low-water bridges usually is modeled as a grate using 1D beam element mesh called a "rod" model. The usage of the 1D beam element mesh for modeling girders of low-water bridges makes it impossible to take into account the actual position of a wooden deck with reference to the neutral axis of these girders. Therefore, this article presents the possibility to use, for modeling main girders, 2D shell elements mesh, creating so-called "coating" models. As a result of numerical analysis it was found that the preferred model for the calculation of the military spans in low-water bridges should be a "coating" model, in which the stiffening of a span's model by a wooden deck was not included in the calculations. This model allows relatively accurate analysis of stress distribution in selected elements of the steel structure of the span, which is important when analyzing the development of fatigue cracks. In the case of the calculations of spans in low-water bridges which are dedicated only to assess the resistance of the selected steel structure of the span, the models using 1D beam element mesh ("rod" models) proved to be sufficient.
\end{abstract}

Keywords: finite element method, low-water bridge, steel structures, span. 
